\title{
Some Strategic Problems in Agricultural Development in Pakistan
}

by

\section{INTRODUCTION}

\section{Ghulam Mohammad*}

Crop yields in Pakistan are amongst the lowest in the world. Food intake is less than 2,000 calories per capita per day; the diet is not balanced and consists mainly of cereals. The average intake of animal protein is only onehalf of the absolute minimum recommended by the FAO ${ }^{1}$. Similarly, yields of export crops are low and foreign-exchange earnings are meagre.

So long as yields of crops remain low, the great bulk of the land will continue to be devoted to growing of subsistence cereals for the human population and there is very little possibility of crop diversification to include more of such nutritive foods as fruits and vegetables. Under such conditions, there is virtually no possibility of diverting any significant acreage from food and cash crops to fodder and feed crops for the animal population.

The major problem in Pakistan is, therefore, to increase the yields of the main food and cash crops. The main proposals under execution or discussion so far have involved two elements: $i$ ) the provision of increased water supplies through large-scale governmental projects, both in East Pakistan and West Pakistan; and ii) increased provision of all inputs, i.e., pure seed of improved varieties of crops, pesticides, fertilizers, tractors and improved implements, credit, and so on in a package programme for the intensive development of various project areas, involving the complete reorganization of the work of the various organizations with responsibilities in agriculture.

This paper takes a different point of view and argues that the immediate need of Pakistan is to make available to farmers large quantities of those lowpriced inputs that can bring about large increases in crop production in relation to the cost incurred. We argue that the two sectors on which efforts should be concentrated for this purpose are the increased availability of fertilizers and the increased availability of water over large parts of the country. We argue that both of these goals can be achieved, in a relatively short period without

*The author is Senior Research Economist at the Pakistan Institute of Development Economics. He is indebted to Drs. Mark W. Leiserson and Stephen R. Lewis Jr., Joint Director and Research Adviser respectively in the Institute, and Mr. Carl Gotsch of the Harvard Advisory Group in the Planning Commission for their valuable comments on the earlier drafts. However, responsibility for the views expressed and for errors is that of the author alone.

1 FAO, Third World Food Survey. (Rome: Food and Agriculture Organization, 1963). 
radical structural reorganization of the government, through greater use of the private sector and of the incentives for gain of the farmers themselves.

It is not the intent here to minimize the contribution of other factors of production or the mass of educational and organizational difficulties that beset the agricultural sector, but it will be shown in the sections that follow that substantial increases in agricultural productivity can be brought about within the framework of existing rural institutions by concentrating on these two sectors and by making only moderate provision for other factors of production.

\section{II: INCREASING THE CONSUMPTION OF FERTILIZERS}

One of the most important developments of the last century has been the creation of the chemical-fertilizer industry which has made possible large increases in crop production in many countries of the world. Very little advantage, however, has so far been taken of this great opportunity in Pakistan or in many other underdeveloped countries. It is true that countries with high consumption of fertilizer have paid attention to other factors such as irrigation, varietal improvement, and disease control and have organized an efficient extension service. Nevertheless, available data do suggest that supply of nutrients is a necessary condition for obtaining high yields, and up to a certain limit, the greater the quantity of nutrients that can be added, the greater the yield 2 .

\section{Fertilizer Trials in Pakistan}

The most extensive series of tests on the effects of fertilizers in East Pakistan were conducted by Drs. Islam and Sulaiman of the Agricultural Research Institute, Tejgaon, Dacca, in collaboration with Dr. Vermaat of the Food and Agriculture Organization of the United Nations. As a result of more than 4,000 trials run on cultivator's fields on aus, aman and boro rice ${ }^{3}$ between 1957/58 and 1962/63, it was concluded that in East Pakistan it was possible to raise paddy ${ }^{4}$ output between 7,000,000 and nearly 10,000,000 tons with the help of fertilizers alone5. Earlier trials conducted at the Agricultural Research Station, Dacca, indicated that nitrogen fertilizer gave economic returns only when used in combination with farmyard manure. No phosphates were tried in those experiments.

2FAO, Possibilities of Increasing World Food Production. (Rome: Food and Agriculture Organization, 1963), pp. 96-109.

3 According to season, the entire rice crop of East Pakistan is divided into three broad groups, namely, aus, aman and boro. The word aus means early and refers to the rice crop sown in March-April and harvested in July-August. The word aman means rice and refers to the main rice crop of East Pakistan which is sown in May-June, transplanted in July-August and harvested in November-December. Boro rice is adapted to cooler season; it is sown in OctoberNovember, transplanted in December-January and harvested in March-April.

4 Paddy refers to rice in husk. Rice is usually two-thirds of paddy by weight.

$5 \mathrm{~J}$. G. Vermaat, Report to the Government of Pakistan on Soil Fertility Problems in Pakistan. (Rome: Food and Agriculture Organization, 1964). 
In West Pakistan, results of experiments conducted by the Department of Agriculture during the last 50 years showed that nitrogen gave a positive response on all crops throughout West Pakistan ${ }^{6}$. Further trials conducted with the help of FAO on cultivator's fields during recent years, i.e., 1959/60-1962/63, showed that the application of a combination of nitrogen and phosphoric acid increased the yield of wheat and other crops and gave economic returns to the farmers in most districts of West Pakistan ${ }^{7}$. The returns were highest in areas which were free from waterlogging and salinity. Only in areas where salinity was excessive was the use of fertilizer found to be not economical.

\section{Fertilizer Requirements of Pakistan}

Based on the results of fertilizer experiments mentioned above and taking into consideration the increases in the cropped areas likely to take place as a result of the irrigation-development programme during the next 20 years, estimates for fertilizer requirements of Pakistan have been prepared by Imhausen International Engineering Company, consultants to the Planning Commission, and by the Revelle Panel. In the Revelle Report the requirements of Indus Plains are estimated at 625 thousand tons of nitrogen and 160 thousand tons of phosphoric acid ${ }^{8}$. Imhausen estimate the total requirements of nitrogen, phosphoric acid and potash for Pakistan at 2.85 million tons 9 . Out of this, 1.18 million tons are estimated for West Pakistan and 1.67 million tons for East Pakistan. Imhausen further recommend that about 725-thousand-ton fertilizer capacity be completed during the third-plan period. When added to the existing capacity, this would raise the total capacity to about 870 thousand tons. For the 65 million acres expected to be under crops in 1969/70, this would mean an average consumption of 30 pounds per acre. This may appear excessive in relation to the existing consumption of 3 pounds per acre but is certainly very low in relation to Pakistan's needs. Efforts should be made to reach or exceed this level in the next 5 years.

This can be done if the following conditions are met:

1) The price of fertilizer should be low: Fertilizers must be made available at a low price in relation to the price of farm products. The example of Japan, which uses 100 times the fertilizer that Pakistan uses, is often quoted, but the

6 A. Wahab, Fifty Years' Research in Soils, Fertilizers and Soil Microbiology. (Lyallpur: Department of Agriculture, West Pakistan, 1960).

7 J. G. Vermaat, op. cit.

8 US White House, Department of Interior Panel on Waterlogging and Salinity in West Pakistan, Report on Land and Water Development in the Indus Plain. (Washington, D.C.: January 1964), pp. 103 and 106. Hereafter referred to as the Revelle Report.

9 Imhausen International Engineering Company, Report on Development of Fertilizer Industry in Pakistan. (Zurich: Noveber 1963), p. 56. 
price factor is often overlooked. In Japan it takes 2.4 pounds of wheat to buy one pound of nitrogen (see, Appendix Table A-I). In Pakistan, on the other hand, it takes 5.0 pounds of wheat to buy one pound of nitrogen at full cost and 2.5 pounds of wheat at the present subsidized cost. Thus, even the subsidized nitrogen is more costly in Pakistan in terms of wheat than the unsubsidized nitrogen in Japan. In East Pakistan, the position with respect to rice is still worse. While in Japan it takes 1.3 pounds of paddy to buy one pound of nitrogen, in East Pakistan it takes 3.5 pounds of paddy to buy one pound of nitrogen at full cost and 1.7 pounds of paddy when fertilizer is sold at a 50-per-cent subsidy.

That price is indeed an important variable may be seen from the history of fertilizer distribution in Pakistan. The Food and Agriculture Commission, after examining this question stated: "In the past, government has subsidized fertilizer to various degrees. The rate of subsidy has, however, been so variable from year to year and changed at such short notice that much of the expected impact of the subsidy was lost.... Fertilizer use is still in its initial phase; and to ensure widespread distribution, it is desirable that the subsidy should continue and that the rate should remain unchanged over a number of years so that the farmer may not be left in doubt as to the investment he has to make"10. As a result of recommendations of the Food and Agriculture Commission, the government decided in 1961 to fix the prices of fertilizers at about 50 per cent of the cost and to keep these prices constant throughout the second-plan period. The use of fertilizer rose from 31 thousand tons in 1959/60 to 55 thousand tons in 1960/61, an increase of 80 per cent in one year. However, at the end of only one year the subsidy was cut from 50 per cent to 25 per cent in West Pakistan, and distribution work was passed on from the Department of Agriculture to the newly created Agricultural Development Corporations (ADCs) in both wings. There was only a small increase in fertilizer consumption during the next 2 years. The government was forced to restore the subsidy to 50 per cent in West Pakistan in the beginning of 1964 .

There is no doubt that if fertilizer had been continued to be imported (or produced) in adequate quantities and if the lower prices for fertilizer introduced in the western wing in 1953/54 had been continued, the consumption would have been many times what it is today.

It is important that the present subsidy of 50 per cent should continue at least upto the end of the third-plan period. If it continues, consumption can be Agriculture Commission. (Karachi: Manager of Publications, September 1960), p. 177. 
expected to increase by about 50 per cent a year. Such an increase would mean that the level of consumption, by $1969 / 70$, would rise to some 800 thousand tons of nutrients, provided that certain other conditions are fulfilled.

2) Adequate credit should be provided: So long as use of fertilizer was on a small scale, lack of credit facilities was not a serious problem. However, if consumption is to be increased to a level of about 800 thousand tons of nitrogen, phosphorus and potash a year, as suggested earlier, the total cost paid by the cultivators in both wings of the country in 1969/70 would come to about Rs. 500 million a year. This would require a large expansion in the amount of credit available.

Total loans provided by the government through the Agricultural Development Bank of Pakistan, the Cooperative Credit Societies and the Taccavi1 1 loans by Revenue Department during the last 3 years are given in Table I:

TABLE I

CREDIT FACILITIES PROVIDED: 1959/60 To 1961/62

\begin{tabular}{lcccc} 
Year & $\begin{array}{c}\text { Taccavi loans } \\
\text { by Revenue } \\
\text { Department }\end{array}$ & $\begin{array}{c}\text { Loans by } \\
\text { Agricultural } \\
\text { Development } \\
\text { Bank of } \\
\text { Pakistan }\end{array}$ & $\begin{array}{c}\text { Loans by } \\
\text { Coop. Credit } \\
\text { Societies }\end{array}$ & Total \\
\hline
\end{tabular}

\begin{tabular}{lcccc}
\hline & $(\ldots \ldots \ldots \ldots \ldots \ldots \ldots$. & & \\
$1959 / 60$ & 34 & 55 & 100 & 189 \\
$1960 / 61$ & 35 & 77 & 117 & 229 \\
$1961 / 62$ & 35 & 95 & 104 & 234 \\
\hline
\end{tabular}

Source: Data provided by the Agricultural Development Bank of Pakistan, Karachi.

The Agricultural Development Bank maintains a record of loans sanctioned for each purpose. Out of Rs. 95 million sanctioned by them during 1961/62, the amount sanctioned for the purchase of fertilizer was only Rs. 2.6 million or less than 3 per cent ${ }^{12}$. The share of fertilizer in loans sanctioned by Cooperative Societies and in Taccavi loans was probably higher. According to a survey on the utilization of loans in the Comilla Thana, 15.6 per cent of loans sanctioned by the Cooperative Credit Societies were utilized for purchase

11 Loans issued by the Revenue Department under the Agricultural Improvement Act and the Agriculturists' Loans Act are popularly known as Taccavi loans. The word Taccavi means help and strength.

12 Agricultural Development Bank of Pakistan, Annual Report and Statement of Accounts for the Year ending June 1962. (Karachi: Agricultural Development Bank of Pakistan, 1963), p. 10 . 
of fertilizer ${ }^{13}$. Assuming the same figure for the Taccavi loans, the total loans sanctioned for fertilizer in 1961/62 by all the three agencies were about Rs. 26 million. These should be increased to about Rs. 500 million a year in the next few years in order to enable the farmers to expand fertilizer consumption rapidly.

3) Efficient fertilizer distribution organization should be set up: Distribution work was in the hands of the Department of Agriculture up to 1960/61 when it was transferred to the Agricultural Development Corporations. The Corporations did not have any field organization for fertilizer distribution. The West Pakistan ADC, therefore, appointed the Cooperative Department as their sale agents which, in turn, organized a Rural Supply Cooperative Corporation for wholesale business and Union Cooperative Societies for retail sale of fertilizer. In 1963/64, it was decided that the West Pakistan Industrial Development Corporation (WPIDC) should appoint its own private agents in addition to the Union Cooperative Societies and agents of the WPADC. The WPIDC has appointed about 500 sale agents at the Mandi (market) towns.

The East Pakistan ADC, lacking distribution facilities, appointed the Department of Agriculture for retail business, so that instead of one we have now two government agencies, handling the same job. The Department of Agriculture had constructed about 4,000 Union stores and had special staff for sale of fertilizer. Performance, however, was unsatisfactory and it was reported that the-Thana stores as well as Union stores remained closed a large part of the time and the cultivators could not buy the fertilizer. This was probably because the store keepers got their pay whether they sold any fertilizer or not. In 1963, the Department of Agriculture appointed a number of private agents for sale of fertilizer in addition to sale from the Union stores. Performance improved considerably, and in the first 10 months of 1963/64, 39 thousand tons of fertilizers were sold as compared with 27 thousand tons in the whole of $1962 / 63^{14}$. The decision to pass on the sale of fertilizer to private enterprise is extremely significant. Private agents have a personal stake in sales and if the profit margins are sufficiently high, an all-out effort to sell large quantities of fertilizer may be expected.

The actual policy to be followed for insuring appropriate profit margins could take two different forms. A system of fixed prices for purchase and

13 Pakistan Academy for Rural Development, Loan Utilization by Co-operative Members of Comilla. (Comilla: Pakistan Academy for Rural Development, March 1964), p. 4.

14 East Pakistan Agricultural Development Corporation, Statement of Sale of Fertilizer Consolidated as per Reports Received from D.A.O.s Offices for the Month of April, 1962. (Dacca: East Pakistan Agricultural Development Corporation, June 1964). 
sale of fertilizers at the factory and at Mandi towns can be followed; in this case an appropriate rate structure must be determined. At current prices, profit margins on the sale of urea amount to 9 per cent in West Pakistan and 11 per cent in East Pakistan, and dealers have to bear godown rent, and some other charges out of this margin of profit. It is unlikely that they will sell much urea under these conditions. Urea is the only fertilizer produced in East Pakistan and the major fertilizer produced in West Pakistan. It is also the major form of nitrogen to be produced in the future. Therefore, it is essential that the profit margin on this fertilizer be increased. The sale of fertilizer can be maximized if it begins to bz sold by village shopkeepers. The private agents now appointed at the Mandi towns will eventually make such arrangements with village shopkeepers if the profit margins are high enough to be shared. A minimum profit margin of 20 to 25 per cent on all fertilizer sales may be necessary.

A second system, probably a better and more efficient policy, would be to fix the price only at one level, appoint a larger number of dealers and let the dealers sell fertilizer at whatever price they can. This is likely to maximize the sales. By having a larger number of dealers there would be keen competition between them and chance of overcharging would be reduced. Even if in some cases they charge higher prices, it is of secondary importance so long as they can sell larger quantities of fertilizers.

4) Cheapest and best fertilizers should be produced: Although the sale of fertilizer is being subsidized and should continue to be subsidized during the next 5 years or so, ultimately the farmers will have to pay the full price. It is, therefore, of utmost importance that the cheapest form of fertilizer consistent with the needs of soils and crops should be produced in the country. For this purpose, nitrogen in the form of urea should be produced in both wings of the country. For phosphoric acid, rock phosphate may be used as such in East Pakistan and single superphosphate should be produced in West Pakistan. These would provide the cheapest and the best combination for both provinces.

The difference that the distribution of cheap rock phosphate in place of costly triple superphosphate could make to the whole fertilizer programme in East Pakistan is likely to be substantial. Suppose it is proposed to distribute 100,000 tons of phosphoric acid. This is equal to 220,000 tons of triple superphosphate $\left(46 \% \mathrm{P}_{2} \mathrm{O}_{5}\right)$ and 300,000 tons of rock phosphate $\left(33 \% \mathrm{P}_{2} \mathrm{O}_{5}\right)$. The price of the fertilizer inclusive of distribution charges, total cost, sale proceeds and subsidy to be borne in the two cases are given in Table II. 


\section{TABLE II}

\section{SALE OF TRIPLE SUPERPHOSPHATE AND ROCK PHOSPHATE: CONTAINING 100,000 TONS OF $\mathbf{P}_{2} \mathrm{O}_{5}$ : COMPARATIVE COST, SALE PROCEEDS AND SUBSIDY}

\begin{tabular}{lcc}
\hline & $\begin{array}{c}\text { Triple } \\
\text { Super- } \\
\text { phosphate }\end{array}$ & $\begin{array}{c}\text { Rock } \\
\text { Phosphate }\end{array}$ \\
\hline $\begin{array}{l}\text { Quantity to be imported (thousand tons) } \\
\text { Price per ton inclusive of distribution charges }\end{array}$ & 220 & 300 \\
$\quad$ (Rs. per ton) & $580^{a}$ & $200^{b}$ \\
Total cost (Rs. million) & 127.6 & 60.0 \\
Sale price (Rs. per maund) & $7.36^{c}$ & $1.00^{d}$ \\
Total sale proceeds (Rs. million) & 44.0 & 8.2 \\
Subsidy borne by government (Rs. million) & 83.6 & 51.8 \\
\hline
\end{tabular}

a) C \& F price Rs. 480 per ton. Distribution charges Rs. 100 per ton. See, EPADC, Scheme for Procurement and Distribution of Fertilizer in East Pakistan. (Dacca: East Pakistan Agricultural Development Corporation, November 1963).

b) C \& F price $\$ 19$ per ton according to Imhausen Report on Development of Fertilizer Industry in Pakistan, op. cit., (p. 130) and $\$ 16$ per ton according to Revelle Report, op. cit., (p. 104). Grinding and distribution charges Rs. 120 per ton. Total Rs. 200 per ton.

c) Existing sale price of triple superphosphate.

d) Proposed sale price of rock phosphate to maximize sale of phosphoric acid.

While it may be difficult to sell 220,000 tons of triple superphosphate at Rs. 7.36 per maund it will be comparatively easier to sell 300,000 tons of rock phosphate at Re. 1.00 per maund. The subsidy to be borne by the government will be much less in the case of rock phosphate. Furthermore, for the wet paddy crop on the acid soils of East Pakistan rock phosphate is likely to be as effective as triple superphosphate per unit of $\mathrm{P}_{2} \mathrm{O}_{5}$ over a period of years as is shown in Appendix C. Due to the complimentarity of fertilizers, increased sale of rock phosphate will also boost the sale of urea, and the total sale of all fertilizers may advance beyond expectations of the government. Therefore, a programme for large-scale imports and trials of rock phosphate should be carried out in East Pakistan for the next few years. Contrary to the recommendations of Imhausen International Engineering Company, triple superphosphate should not be produced in East Pakistan unless large-scale trials have been conducted with rock phosphate over a period of years. For West Pakistan, single superphosphate would be better than triple superphosphate and factories should be located in the farming areas and not at Karachi, again contrary to recommendations of Imhausen. The reasons for this are given in Appendix $\mathbf{C}$. 
5) Transport and storage facilities should be extended: As fertilizer consumption increases, the tonnage of fertilizer to be handled during the next few years will place a severe burden on the transport facilities in the country. The total tonnage of fertilizer to be handled at the end of next 5 years may be expected to reach one million tons in East Pakistan and $1 \frac{1}{2}$ million tons in West Pakistan.

Demand for fertilizer is seasonal. Therefore, adequate storage facilities with a total capacity of about half a million tons in each wing, located in fertilizer factories, at a number of strategic places from distribution point of view, at the Mandi towns and at the Union level should be constructed so that fertilizer can be moved throughout the year, particularly when rail, road or boat facilities are more readily available.

6) Demonstration and experiments on cultivators' fields should be arranged: Fertilizer trials on cultivators' fields have been conducted at 50 centres, roughly one in each subdivision in East Pakistan and in 14 out of 45 districts of West Pakistan. It is essential that these trials be laid out in each Union in East and West Pakistan in order to obtain realistic information on physical and economic crop-responses to various fertilizers on various soils under practical farming conditions. All the 4,000 Union Assistants in East Pakistan and 3,000 Field Assistants in West Pakistan as well as the 1,000 Thana Agriculture Officers and Tehsil Agriculture Assistants should be thoroughly trained in laying out these fertilizer trials on cultivators' fields,

An important component of correct fertilizer use is soil testing. This should be done in conjunction with field experiments and soil testing laboratories should be established. In addition soil-testing kits should be provided to the staff at the Thana/Tehsil level. The cost of a soil-testing kit is less than Rs. 100. Total cost for 400 Thana Agricultural Officers and 600. Tehsil Agricultural Assistants would be less than Rs. 100,000.

The extension staff has a multiplicity of duties to perform. While all the duties assigned to them are necessary for ideal programme, it may be desirable to put major emphasis on the use of fertilizer alone for the next few years. The extension staff must know exactly what combination of fertilizers to use in different areas for different crops and how and when to apply the fertilizer. They should be able to advise the farmers accordingly. The success of the extension staff should be judged on the basis of correct fertilizer use and all Union Assistants, Thana/Tehsil Agricultural Officers and District Agricultural Officers who bring about more than 50 per cent increase in fertilizer use year after year should be given bonus or some other form of encouragemen $t$. 
7) Improved high-yielding varieties should be evolved: In order to expand fertilizer consumption on a large scale, it is essential to have varieties of crops which make use of high doses of fertilizer, and can, thus, give large increases in yield. Such varieties of rice have not been evolved because there is very little research staff for work on the breeding of rice. Japan with 8 million acres under rice has a National Institute, 7 Regional Institutes and 350 Experiment Stations. Similarly, the Philippines with 8 million acres under rice has the advantage of the International Rice Research Institute at Manila with a competent faculty larger than the whole of research staff in East Pakistan. Against this, East Pakistan with 21 million acres under rice has only one small research section under a Cereal Botanist with a few Assistants who work on rice as well as on seven other crops. Not much can be accomplished under such conditions. It may be more profitable to redesignate the Agricultural Research Institute, Dacca, as Rice Research Institute and to put the whole staff working on all crops other than jute under the charge of a Director of Rice Research Institute to concentrate research on rice. High-yielding varieties which make use of larger doses of fertilizer should be evolved by introduction of or hybridization with Japonica types of rice because there can be no improvement in East Pakistan's agriculture until the yield of rice is increased.

In West Pakistan, the situation is somewhat better, but here too, appropriate priorities have not been applied in determining research efforts. Wheat occupies more than 12 million acres in West Pakistan, and again the need is to develop varieties which have as a primary attribute a high tolerance for fertilizers so that the yield of wheat increases and part of the area can be diverted from wheat to other crops.

While much good work on cereals has been done, for example, at Lyallpur where a number of improved varieties of wheat have been evolved, the staff of the Cereal Botanist, Lyallpur, is no larger than that of some other sections concerned with minor crops. Commonsense would seem to indicate the necessity for strengthening sections devoted to major crops, since changes in the agricultural structure of the province hinge on the ability to raise substantially the yields of the main crops.

\section{Prospects}

Fertilizer distribution work in the past has suffered from frequent changes in prices resulting from frequent and abrupt changes in the rate of subsidy, lack of availability of fertilizer due to nonavailability of foreign exchange in some years and inefficient organization for distribution work throughout these years. When fertilizer was made available at low prices and extension staff was 
put on educating the farmers on the use of fertilizer, increases in fertilizer consumption were substantial.

It has been shown in this paper that even the present subsidized prices of fertilizer are higher than the unsubsidized prices of fertilizer in Japan in terms of prices of wheat and rice in the two countries. If fertilizers are sold at a price low in relation to the price of wheat and paddy with which the cultivators have. to buy the fertilizer, if an efficient distribution system is organized, if transport and storage facilities are expanded, if the extension staff advises the farmers on the correct use of fertilizer and if only those fertilizers are produced in the country which are best suited to the needs of soils and crops of Pakistan and which can be supplied to the farmers at the lowest possible prices, sale of fertilizer could expand by about 50 per cent a year and reach a level of 800,000 tons of nitrogen, phosphoric acid and potash by $1969 / 70$. This is against 472,000 tons proposed by the Planning Commission 15 .

Assuming a total consumption of about 800,000 tons in $1969 / 70$ against 150,000 tons in $1964 / 65$, there will be an increase of 650,000 tons during the third-plan period. Out of this about 450,000 tons of fertilizer may be expected to be used on foodgrains in both provinces. Assuming an increase of 10 pounds of foodgrains for each pound of plant nutrient applied, as estimated by the FAO ${ }^{16}$, we may expect an increase of about 4.5 million tons of foodgrains by the use of fertilizer alone. This is compared with an increase of 4 million tons of foodgrains estimated by the Planning Commission from all factors of production.

\section{III: TUBEWELLS FOR ADDITIONAL WATER SUPPLY}

\section{A. WEST PAKISTAN}

All over West Pakistan, the average yields of crops are very much below what may be considered satisfactory for irrigated land under similar climatic conditions. One basic cause of this is that much less irrigation water is available than is required for consumptive use of crops.

One cusec of water is generally supplied for 333 acres in West Pakistan as against 100 acres or less in the United States of America and other countries under similar climatic conditions ${ }^{17}$. Most important changes in the agriculture of West Pakistan can, therefore, be expected from the use of additional irrigation water on the presently cultivated areas.

15 Government of Pakistan, Planning Commission, Guidelines for the Third Five-Year Plan (1965-70). (Karachi: Manager of Publications, November 1963) p. 62.

16 Possibilities of Increasing World Food Production, op. cit., p. 108.

17 C.E. Mairhofer, Reconnaissance Report, Drainage, Waterlogging and Salinity Problems of the Indus Plain. (Denver: U.S. Bureau of Reclamation, October 1952), p. 10. 
There are two sources of additional water supply. One is the main river and tributory storage of water, more than 60 million acre feet of which now passes unused into the Arabian Sea during periods of high run-off and which can be stored for regulated use throughout the year. The other source is the ground water. The possibilities of the development and use of additional surface supplies are being investigated by West Pakistan Water and Power Development Authority (WAPDA) with the help of the International Bank for Reconstruction and Development and will not be considered here. This section is devoted to the role of tubewell irrigation in the development of agriculture.

\section{Government Tubewells}

Underneath the plains of the former Punjab and Bahawalpur lies a vast reservoir of water which can be used to: supply large quantities of water by tubewell pumping. In order to make use of this reservoir, installation of tubewells was started on a small scale in the Punjab in 1938 when 20 tubewe!ls were installed in the Shalimar Garden. After that about 1,500 tubewells were installed in the Rechna and Chaj Doabs between 1944 and 1953 and began working in 1954. It was noticed that within a period of 5 to 10 years of the installation of tubewells their discharge declined from an average of 2 cusecs to 1.4 cusecs. Some of these tubewells had to be closed after 8 years' working due to uneconomic yields. In order to determine the causes of decline in the discharge, the strainers of some of the tubewells were recovered and it was found that a thin layer of incrustation, on the inside of the strainer, had completely blocked the strainer slits ${ }^{18}$.

The West Pakistan Water and Power Development Authority prepared in 1961 a masterplan for the control of waterlogging and salinity in West Pakistan by the installation of 31,000 tubewells, 7,500 miles of major drains and 25,000 miles of supplemental drains at a total cost of Rs. 590 crores $^{19}$. In the Revelle Report, the total cost for land and water development in the Indus basins is estimated at $\$ 2.3$ billion or Rs. 11,000 million ${ }^{20}$. This includes cost of fertilizer, plant protection and improved seed. If these are excluded, the cost would be $\$ 1.8$ billion or Rs. 8,600 million $^{21}$.

Under the WAPDA masterplan, 1,800 tubewells have been installed in Salinity Control and Reclamation Project Number One (SCARP 1), in the

18 Sarwar Jan Khan, "Efficacy of and Dependence on Tubewells as a Means of Providing Additional Supply Necessary for Controlling Salinity and Reclaiming Water-logged Areas", Symposium on Water-logging and Salinity in West Pakistan. (Lahore: West Pakistan Engineering Congress, October 1963), pp. 207-209.

19 West Pakistan, WAPDA, Programme for the Control of Water-logging and Salinity in the Irrigated Areas of West Pakistan. (Lahore: West Pakistan Water and Power Development Authority, May 1961).

20 Revelle Report, p. 165

21 Ibid. 
Rechna Doab. Another project for the installation of 3,300 tubewells in Salinity Control and Reclamation Project Number Two (SCARP 2) in the Chaj Doab has been sanctioned at an estimated cost of Rs. 300 million.

The average cost of the tubewells in SCARP 1 and SCARP 2 is estimated at Rs. $83,000^{22}$ and Rs. $116,000^{23}$ per tubewell respectively. In SCARP 3 it is proposed to install 1,550 tubewells at a total cost of Rs. 220 million $^{24}$. The average cost of these would, thus, be about Rs. 142,000 per well.

Working of tubewells in SCARP 1 commenced in 1960/61. By September 1963, the watertable had been lowered by about 7 feet 25 , and the total area cropped had increased by 250,000 acres or about 25 per cent over the preoperation periods 26 . The value of crops was estimated to have increased by 40 per cent ${ }^{27}$.

\section{Private Tubewells}

The farmers of the Punjab, with the help of the Department of Agriculture and private drilling concerns, have installed some 10,000 tubewells with their own funds. The Department of Agriculture started drilling in 1950/51 when 63 tubewells were installed. Tubewells of various sizes have been installed but tubewells of 1 to 1.5 cusecs capacity are the most popular. The Department undertake the drilling of bore holes, and installation of pipes and strainers. The remaining work, supply and installation of pump and engine and the construction of the pumphouse, etc., is done by the farmers themselves. Pipes and strainers may be purchased by the farmers from the Department of Agriculture or from the local market.

The Agricultural Engineer, Lyallpur, has installed about 5,000 tubewells during the last 13 years. In addition, the Department of Agriculture has 6 other Agricultural Engineers, located at Peshawar, D. I. Khan, Khanpur, Quetta, Khairpur and Hyderabad. These Agricultural Engineers have taken up installation of tubewells for the farmers in recent years. The Department of Agriculture

22West Pakistan WAPDA, Review of Project Number One. Salinity Control Programme in West Pakistan. Prepared by Tipton and Kalmbach Inc. (Denvor: Tipton and Kalmbach, June 1959), p. 35.

${ }^{23}$ West Pakistan, WAPDA, Feasibility Report on Salinity Control and Reclamation Project Number Two. Prepared by Tipton and Kalmbach Inc. (Denvor: Tipton and Kalmbach, 1960), Appendix G.

24 West Pakistan, WAPDA, Feasibility Report on Salinity Control and Reclamation Project No. 3. Lower Thal Doab. Prepared by Tipton and Kalmbach, Inc., (Denvor: Tipton and Kalmbach, Inc., April 1963), p. 48.

25 West Pakistan WAPDA, Progress Report for the Operation of Salinity Control and Reclamation Project No. 1 for the Period October 1962 to September 1963. (Lahore: November 1963), p. 6.

26 lbid., p. 8.

27 Harza Engineering Company International, Programme for Water and Power Development in West Pakistan through 1975. (Lahore: January 1964), p. 47. 
have 150 drilling rigs and plan to have 163 more rigs 28 . Their capacity will increase from the existing level of 1,400 tubewells to about 3,000 tubewells within one year 29 .

In addition, a number of private firms are engaged in the installation of tubewells. Unfortunately, no statistics on tubewells installed by these firms are available. On the basis of enquiries made in the villages, it seems that these firms are installing at least as mony tubewells in a year as the Department of Agriculture. The total number of tubewells installed by the farmers must have exceeded 10,000 by now and the number installed would now be about 3,000 a year. The rate of installation is increasing year by year and could reach 5,000 to 6,000 tubewells a year in the next few years.

The cost of installation of a tubewell of one cusec discharge with 10-inch boring rig and 6-inch brass strainer with watertable at $20 \mathrm{ft}$. depth is estimated by the Department of Agriculture at Rs. 14,00030. Farmers generally spend much less. They use a coir strainer which costs only Rs. 6 per foot for a 6-inch size instead of brass strainer which now costs about Rs. 30 per foot. They use their own labour and, thus, reduce these charges. They spend only a few hundred rupees on the pumphouse instead of Rs. 2,800 estimated by the Department of Agriculture.

The Pakistan Institute of Development Economics has carried out a survey of 32 private tubewells located in different districts of the Punjab31. Thirty of these tubewells had coir strainers and the average cost of installation of these was Rs. 8,300 per well (Rs. 9,600 for diesel-driven wall and Rs. 7,800 for electricdriven well). These tubewells have about 80 feet of blind pipe and about 90 feet of strainer. They are fitted with an engine or motor of about 18-20 horsepower. Average discharge for all tubewells was 1.25 cusecs. A majority of the tubewells, 26 out of 32, had a discharge between 1 and 1.5 cusecs. They worked about 3,000 hours in a year and pumped about 300 acre-feet of water per well. About 20 per cent of the water was sold to the neighbouring cultivators by the owners.

One holding on each of the 32 tubewells was selected and cropping of these holdings noted. Before the installation of tubewells, these holdings had 84-per-cent intensity of cropping which was increased to 134 per cent after

28 Government of Pakistan, Planning Commission, Memorandum for the Pakistan Consortium, 1964-65. (Karachi: Manager of Publications, April 1964), p. 80.

29 One drilling rig generally installs one tubewell in a month.

30 Majid Hasan Khan, Wells and Tubewells. (Lahore: Department of Agriculture, West Pakistan Government, 1959), p. 18.

31 Fieldwork for this survey was done by Mr. Mohammad Ghaffar, a Research Assistant in the Institute, to whom the author is grateful. 
the tubewells were installed ${ }^{32}$. Increase in the area cropped was thus 60 per cent over the pretubewell period. Fertilizer consumption increased 15 fold and the total value of crops increased by more than 100 per cent after the installation of tubewells ${ }^{33}$.

\section{Comparison of Government and Private Tuberrells}

It is a common knowledge that work done by Public Works Departments costs much more money than similar work done by private citizens for their own use. This observation is borne out when private tubewells are compared with government tubewells on the basis of equivalent discharges. The cost of government tubewells installed or proposed to be installed in various SCARP areas and cost of private tubewells is given in Appendix Table B-I, and is summarized below in Table III:

TABLE III

COMPARATIVE COST OF GOVERNMENT AND PRIVATE TUBEWELLS

\begin{tabular}{|c|c|c|c|c|}
\hline Item of cost & $\begin{array}{c}\text { SCARP-1 } \\
\text { tubewells } \\
\text { of } 3.0 \\
\text { cusecs }\end{array}$ & $\begin{array}{c}\text { SCARP-2 } \\
\text { tubewells } \\
\text { of } 3.55 \\
\text { cusecs }\end{array}$ & $\begin{array}{c}\text { SCARP-3 } \\
\text { tubewells } \\
\text { of } 3.9 \\
\text { cusecs }\end{array}$ & $\begin{array}{l}\text { Private } \\
\text { tubewells } \\
\text { of } 1.25 \\
\text { cusecs }\end{array}$ \\
\hline \multirow[t]{2}{*}{ (1) } & (2) & (3) & (4) & (5) \\
\hline & \multicolumn{4}{|c|}{ 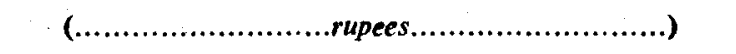 } \\
\hline $\begin{array}{l}\text { 1) Cost of installation of tube- } \\
\text { wells }\end{array}$ & 51,400 & 54,300 & 79,700 & 7,860 \\
\hline $\begin{array}{l}\text { 2) Cost of drains for removal } \\
\text { of saline water }\end{array}$ & - & 20,000 & 12,300 & - \\
\hline 3) Total cost of tubewells & 51,400 & 74,300 & 92,000 & 7,800 \\
\hline $\begin{array}{l}\text { 4) Cost of electric-transmis- } \\
\text { sion facilities }\end{array}$ & 32,100 & 41,500 & 49,800 & $?$ \\
\hline $\begin{array}{l}\text { 5) Total cost of tubewell inclu- } \\
\text { sive of electric-transmission } \\
\text { facilities (Rows } 3 \text { and 4) }\end{array}$ & 83,500 & 115,800 & 141,800 & $?$ \\
\hline
\end{tabular}

6) 1.25 cusecs tubewell without $21,400-26,200-29,500$

Apportioned cost for 1.25 cusecs electric-transmission facilities 21,400 26,200

29,500 7,800

7) Foreign-exchange compo13,200 13,500 15,300 nent of Row (6)

Source: Appendix Table B-I.

32 The term "intensity of cropping" is used to denote the areas of land cropped in a given year as a percentage of the cultivated land that could be cropped in one year. If the land is completely sown to crops, both summer and winter, there is 200-per-cent intensity.

33 This is confirmed by the records of yield obtained at the Agricultural Experiment Station, Montgomery, where a tubewell was installed in 1962/63 and yields in one year increased by 30 to 60 per cent over the previous 4 years. This information was supplied to the author in March 1964 by the Manager of the Agricultural Experiment Station at Montgomery. 
- The total cost of government tubewells is 3 to 4 times the cost of private tubewells and has continued to increase over time. In SCARP 1, the cost of a tubewell without electric-transmission facilities was Rs. 21,400 for a discharge of 1.25 cusecs, which was 2.7 times the cost of a private tubewell of the same discharge. In SCARP 2, the cost for the same discharge increased to 3.4 times the cost of private tubewells, whereas in SCARP 3 cost is estimated to be 3.8 times that of the private tubewells.

On the other hand private manufacturers are trying to lower the cost of their installation so that a tubewell of 1-cusec capacity can now be installed for 5 to 6 thousand rupees according to a survey by the Irrigation Research Institute ${ }^{34}$.

Foreign exchange worth Rs. 13,000 to Rs. 15,000 is required for a government tubewell of 1.25 cusecs exclusive of electric-transmission facilities. In private tubewells, the foreign-exchange required is less than one-fourth of this amount.

The cost of SCARP tubewells is high but they were expected to have a much longer life. The average life of these tubewells was estimated at 40 years by Tipton and Kalmbach ${ }^{35}, 30$ years in the Revelle Report ${ }^{36}$ and 20 years by Harza Engineering Company International ${ }^{37}$. However, a serious problem has come to light regarding the working of SCARP-1 tubewells during the past 3 years. It has been noticed that discharge of tubewells installed in two of the 12 schemes included in SCARP 1 has already been reduced by 26 and 28 per cent respectively ${ }^{38}$. Recent studies carried out by the Irrigation Research Institute, Lahore, indicate that in two more schemes in this area, the discharge has been reduced by as much as 40 per cent within a period of 3 years ${ }^{39}$. It is, therefore, unlikely that these tubewells will last for 40,30 or 20 years. Furthermore, according to a Chief Engineer of the Irrigation Department, the economic pumping limit of 40 feet pumping head would be reached in 10 years in these tubewells and pumping beyond that period would be uneconomical 40 .

34 Nazir Ahmad and Mohammad Sadiq Sheikh, A Statement of Coir String Strainer Tubewells Installed bv Farmers in the Ex-Punjab and Bahawalpur Area. (Lahore: Irrigation Research Institute, 1963), p. 5. p. 80 .

35 Feasibility Report on Salinity Control and Reclamation Project Number Two, op. cit.,

36 Revelle Report, op. cit., p. 326.325 p. 49.

37 Programme for Water and Power Development in West Pakistan through 1975, op. cit.,

38 Revelle Report, op. cit., p. 317.

39 Nazir Ahmad, Mohammad Sadiq and M. A. Qureshy, A Study of Performance of Different Types of Strainers Installed in An Area between Upper Chenab Canal and Shikarpura Commonly Known as Shadman and Chichoki Mallian Reclamation Schemes. (Lahore: Irrigation Rese irch Institute, 1964).

40 Sarwar Jan Khan, op. cit., p. 209. 
The life of private tubewells put in by farmers with the help of Department of Agriculture and private firms is estimated at 10 years 41 . However, out of the 63 tubewells installed by the Department of Agriculture in 1950/51, 48 tubewells ( 75 per cent) were reported to be in working condition in the 10th year of their life and were giving a discharge of one cusec each. The life of these tubewells may, in fact, turn out to be only slightly less than those put in by the government in SCARP areas.

Working of private tubewells is likely to result in higher additional production as compared to the government tubewells. When a farmer spends Rs. 8,000 and installs a tubewell, he must make the best use of the water. On the other hand, if the government spends the money on tubewells and does not charge anything, the farmer does not have to make the same efforts. This hypothesis is confirmed from the cropping intensity achieved by the farmers of private tubewells who increased their cropping intensity by about 60 per cent after the installation of tubewells as against an increase of only 25 per cent in cropping intensity achieved in the SCARP-1 area. Due to higher yields of crops obtained, the total value of crops increased by more than 100 per cent on the lands of 32 holdings on private tubewells as against an increase of only 43 per cent reported by Harza for SCARP-1 area.

Cost of operation of private tubewells is less than that of the government tubewells. The Pakistan Institute of Development Economics carried out a study on cost of working of 22 electric-driven tubewells in the former Punjab in March 1964. The results, along with the estimates of diesel-driven wells by the Superintending Engineer, Agricultural Machinery Organization, Lyallpur, are given in Appendix Table B-II. The average cost comes to about Rs. 4 per acre irrigation on private electric-driven tubewells. This is against Rs. 5 to 6 per acre irrigation on government tubewells 42 .

There is one more difference which may be of crucial importance for policy decision in the immediate future. Private tubewells are generally located in nonsaline groundwater areas. A farmer will not invest money in a tubewell from which the water cannot be used for irrigation purposes. Many of the government tubewells are installed in areas where the water is too saline to be used for irrigation. According to a report of the Soil Reclamation Board, out

41 Majid Hasan Khan, Appraisal of Work Done by the Agricultural Machinery Organization, Northern Zone. (Lahore: Department of Agriculture, West Pakistan Government, 1960), p. 5 .

42. Cost of pumping water is estimated at Rs. 19 per acre foot in the Revelle Report (p. 36) One acre foot is equal to 4 acre irrigations. Therefore, the cost per acre irrigation is Rs. 4.75. Life of tubewells is assumed to be 30 years in the Revelle Report. If the life were assumed to be 15 years, the cost would be Rs. 6 per acre irrigation. Cost of electricity for government tubewells is charged at Rs. 0.065 per $\mathrm{kwh}$, whereas private tubewell-owners have to pay Rs. 0.08 per kwh. If the same price were used for government tubewells, their cost would be still higher. 
of 1,236 million acres of land in SCARP 1, 0.896 million acre (72 per cent) falls in the brackish water zone and the quality of subsoil water varies from "totally unfit for irrigation purposes to fit for irrigation after mixing with canal water in 1.1 ratio" 43 .

A main consideration for the installation of the tubewell in areas with groundwater unfit for irrigation is for lowering the watertable. However, it has been seen that the regional watertable has been lowered in the whole of SCARP-1 area even where tubewells did not start working till the beginning of 1963. Two hundred and forty three tubewells in SCARP-1 area were commissioned between October 1962 and September 1963. Actually, 100 out of these have not been worked at all. But the regional watertable in the whole of this area has been lowered due to the working of other tubewells in the adjacent areas.

In light of this extremely significant development, the final proposal of the Revelle Report that the entire aquifer of the northern plain of $\mathbf{3 0}$ million acres be mined and 56 per cent of the tubewells be located inside the cultivated area and 44 per cent be located outside the cultivated area, appears to be highly questionable 44 .

If canal-water seepage from 19 million acres of culturable commanded area could raise the watertable over the whole area of 30 million acres, it raises the question whether pumping of water from 19 million acres of culturable commanded area would not result in lowering the watertable over the whole area of 30 million acres. Working of SCARP-1 tubewells indicates that it may do so and, therefore, it may not be necessary to install any tubewells in areas which are not to be cultivated. It should also be considered whether the government would be able to recover the very high cost involved in installing the tubewells in uncultivated areas and then transporting the water to the cultivated areas, when it has not been able to recover the comparatively lower cost of operation of tubewells located inside the SCARP-1 area. It seems difficult to justify the recommendation in the final Revelle Report on technical or economic considerations.

The total cultivated area of the Punjab and Bahawalpur where underground water is fit for irrigation is about 12 million acres ${ }^{45}$. This area would need

43 Directorate of Land Reclamation, West Pakistan, Progress of Reclamation in Soil Reclamation Schemes of Project One. (Lahore: Directorate of Land Reclamation, November
1962), p. 13.

44 Revelle Report, op. cit., p. 322.

45 Estimates made on the basis of Table 1 in the article by M. Maasland, J. E. Priest and M.S. Malik, "Development of Groundwater in the Indus Plains", Symposium on Waterlogging and Salinity in West Pakistan. (Lahore: West Pakistan Engineering Congress, October 1963),
pp. 146-147. 
about 60,000 tubewells of 1 to 1.5 cusees capacity if each tubewell serves about $\mathbf{2 0 0}$ acres for which irrigation water is already available. Probably 10,000 tubewells have already been installed in this area. The farmers of the Punjab and Bahawalpur are now installing about 3,000 tubewells a year in this area and could install about 5,000 to 6,000 tubewells a year during the next few years. Farmers could, therefore, install all the 50,000 tubewells in the next 10 years if the government would let them do it. They could install them in five years if the government would help them.

The most critical problem in the execution of the whole programme by the farmers themselves is likely to be the provision of electric-transmission facilities for the operation of tubewells. The West Pakistan Government should concentrate on providing electric-power facilities to this area of 12 million acres. There are probably about 12,000 villages in this area. If electric-power facilities can be provided to the whole of this area, in the next 5 years, and electric charges for private tubewells are reduced to the level of government tubewells, the farmers can put in all the 50,000 tubewells during the third-plan period without any cost being incurred by the government on the installation of tubewells.

Another problem likely to arise in the execution of the programme at a fast rate is the availability of blind pipes for the tubewells. These are now being imported and sold by the Department of Agriculture at Rs. 10 per foot. The market rate for these is about Rs. 18 per foot. Average length of blind pipe in a tubewell is about 100 feet which would cost about Rs. 1,000. For 50,000 tubewells the cost would be Rs. 50 million. If blind pipes can be produced in the country, or imported under commodity aid, or if the Department of Agriculture were allocated foreign exchange at the rate of about Rs. 10 million a year for import of blind pipe and its sale to the farmers, all the 50,000 tubewells could be installed within 5 years.

A third problem would be provision of medium- and long-term credit for the farmers. Out of 32 private tubewells studied by this Institute, only 6 had been installed with funds borrowed from Agricultural Development Bank or other sources. The average amount of loan taken was Rs. 7,500 for these 6 tubewells. For all the 32 tubewells this gives an average of Rs. 1,400 per tubewell. The farmers are likely to save and invest a major part of the Rs, 400 million required. However, most of the additional tubewells will be installed by the farmers of small means. Therefore, considerable credit will have to be made available. 
In order to maximize the pumping of water from private tubewells, charges for electricity should be reduced from the present level of Rs. 0.08 per kwh to Rs, 0.05 per kwh proposed for the government tubewells in the Revelle Report. It may be desirable even to reduce them still further to Rs. 0.04 per kwh and subsidize the use of electricity for pumping of water from tubewells to expand the installation programme at a fast rate. Recovery of canal water rates on the bais of volume of water delivered rather than on the basis of area of crops irrigated will further encourage the installation of tubewells.

In Sind, probably one million acres or more could be developed by similar tubewells ${ }^{4}$. About 5,000 tubewells in all would be required for this purpose. Out of this the farmers have put in about 1,000 tubewells. Rate of installation of tubewells by the farmers with the help of the Department of Agriculture is about 200 tubewells a year.

The above programme of private tubewells by the farmers would cover about 13 million acres. The groundwaters in the remaining areas are saline. The Revelle Report proposes that tubewells should be put in the whole of this area, and that two-thirds of the saline water be used on crops and one-third be exported. Bower and Maasland studied the waters of tubewells in SCARP1 area and found that 39 per cent of these were hazardous because of the high sodium and carbonate content of the water ${ }^{47}$. They concluded that the sodium hazards of Punjab groundwaters need further study. It would, therefore, be desirable not to put any tubewells in the saline groundwater areas until the effect of pumping of saline waters on soils in SCARP-1 area has been further investigated. For these areas, tiled fielddrains, combined with open collector drains, may prove to be better than tubewells 48 . Some additional canal-water supplies can be arranged for these areas by enlarging the capacity of canals to use the summer flood-water discharges which now go unused to the sea.

\section{Prospects}

A comparative study of the government tubewells installed in the Rechna and Chaj Doabs (particularly in SCARP areas) and some tubewells installed by farmers with the help of the Department of Agriculture and private firms indicates that the cost of installation of private tubewells is only about one-third of the cost of government tubewells when both are measured

46 The Revelle Report estimates the total area underlain by good-quality water as 2.5 million acres out of which 1.3 million acres lie within the bunds of the Indus river (p. 284). The actual culturable commanded area fit for tubewells is, thus, only 1.2 million acres.

47 C. A. Bower and M. Maasland, "Sodium Hazard of Punjab Ground Waters", Symposium on Waterlogging and Salinity in West Pakistan. op. cit., pp. 49-61.

48 C. E. Mairhofer, op. cit., pp. 17-23. 
on the basis of equal discharges. Yet the increase in agricultural production is far higher in the case of private tubewells than in the case of government tubzwells. From an economic point of view, tubewells should, therefore, be installed by the farmers and not by the government.

There are some 12 million acres of cultivated land in the Punjab and Bahawalpur and one million acres in Sind where the groundwaters are fit for irrigation when mixed with canal waters. These areas would need about 55,000 additional tubewells of the type already installed by the farmers. If the government devotes its whole effort on the provision of electric-transmission facilities to this area, the farmers can install all the tubewells without any cost to the government. The increase in agricultural production may be expected to be more than 100 per cent in these 13 million acres. The value of agricultural production in these areas is more than 40 per cent of the total agricultural production of West Pakistan 49 . Installation of tubewells in these areas could raise the value of total agricultural production by over 40 per cent in the whole of West Pakistan. This may take about 10 years if the farmers are left to their own resources or could be done in 5 years if government concentrates on supplying cheap electricity to this area and the farmers are encouraged to install tubewells by making blind pipes available and by providing greater credit facilities.

It may be preferable not to disperse the efforts and to leave out the remaining 8 million acres of culturable commanded area in the Punjab and Bahawalpur and 11 million acres in Sind for the present. Experimental work on alternative methods of development of this area should, however, continue during the third-plan period.

\section{B. EAST PAKISTAN}

East Pakistan is characterised by heavy rainfall accompanied by high floods from the rivers in summer followed by a long period of drought in the winter. Agricultural practices have adjusted themselves over the centuries to the rhythm of the monsoon. One typical practice is to start an early aus paddy crop with the first premonsoon showers in March or April, to harvest the aus paddy in July and to follow immediately with a transplanted aman paddy crop, which is harvested in December. In small areas a third winter-crop is also obtained. But major part of the area grows only one crop a year. Paradoxically, floods and drought are the main causes of crop failures and low productivity in East Pakistan.

Extensive areas of the province are inundated due to high flood-levels of rivers and by abnormal rainfall or by both factors combined together. On the

49 Calculated from the Revelle Report, Tables 1.7 through 1.11 .2 (pp. 75-82). 
one hand, the early-sown uus crop generally suffers from drought before the monsoon sets in. On the other hand, late-sown aus usually suffers because the young plants cannot stand the submerged conditions caused by early floods. Rainfall varies from 50 inches in the western part to about 250 inches in the north-eastern part of the province. Prolonged breaks in the monsoon may occur during July and August when the young aman crop needs water the most. Also the monsoon may terminate early and drought may often prevent the full maturing of grain and greatly reduce the yield of aman. Sometimes flood waters drown young aman seedlings. In some years the flood rises so fast that even deep-water aman paddy cannot keep its head above water. During the rabi 50 season much of the area remains unsown for lack of moisture. Crops that are sown give very poor yields due to lack of water.

Irrigation, flood control, and drainage can provide the solution to the prevention of crop failures. Provision of assured water supply would also provide favourable conditions for extensive use of fertilizers and high yields of crops. It would enable large increase in crop acreages and production in the rabi season. According to Teensma, yields of most crops, kharif ${ }^{51}$ as well as rabi, could be increased by 200 per cent if irrigation water and fertilizer use were accompanied by good farm-management practices 52 .

The climate of East Pakistan is suitable for growing 3 crops a year. However, out of 21.6 million acres under cultivation, actual area under crops in $1962 / 63$ was 15.1 million acres in the aus season, 16.6 million acres in the aman season, and 5.1 million acres in the rabi season ${ }^{53}$. If floods could be controlled and irrigation facilities provided, the area under crops could be increased by 6.5 million acres in the aus season, 5.0 million acres in the aman season and 16.7 million acres in the rabi season. It should, therefore, be possible to increase the gross area under crops by 28.2 million acres.

Extensive areas in East Pakistan comprising some 8 to 9 million acres are deeply inundated during the monsoon. A general survey of the possibilities of irrigation made by Dr. W.J. Van Blommestein of Food and Agriculture Organization of the United Nations in 1952 indicated that out of 22 million

50 Rabi means spring. It refers to winter crops which are harvested in spring.

51 Kharif means autumn. It refers to summer crops which are harvested in autumn.

52 B. Teensma, Interim Report to the Government of Pakistan on Soil Fertility Problems in East Pakistan with Special Reference to the Ganges Kobadak Area. (Rome: Food and Agri-

53 In the above calculations, 6.1 million acres under broadcast aman, which is sown in April and harvested in December, is counted both in the aus season and aman season. Similarly, whole of the jute is counted in the aus season and part (which is harvested late) in the aman season. Sugarcane, fruits, betelnuts and tea which occupy the land for the whole year
are counted in all the three seasons. 
acres under cultivation, 13 million acres are not subject to inundation or are only inundated in part ${ }^{54}$. In Dr. Blommestein's judgement these 13 million acres could be irrigated by canal system fed by pumping stations or by barrages. However, the Food and Agriculture Organization consider that the whole 13 million acres could be assured of freedom from inundation only with a very complete system of flood control. Where seasonal inundation cannot be avoided, a system of irrigation based on canals is impossible 55 .

The question of flood control is being studies by the East Pakistan Water and Power Development Authority (WAPDA) and is outside the scope of this paper. However, as was pointed out by the 1957 United Nations Technical Mission to Pakistan the problem of controlling floods in East Pakistan is exceedingly difficult and costly and it will take many years and resolute efforts to plan and implement the major flood-control programme ${ }^{56}$. The International Bank for Reconstruction and Development have now undertaken to form a high-level study group to consider all aspects of the problem and to recommend future development alternatives ${ }^{57}$.

In the following pages an attempt is made to see what water development projects can proceed in the meantime without very heavy cost involved in relation to the benefits expected. Four major irrigation projects are now under execution in East Pakistan: i) canal irrigation in the Ganges-Kobadak area, ii) Government tubewells in the North-Bengal area; iii) low-lift power pump irrigation in the Dacca-Mymensingh-Sylhet depression; and iv) small tubewells in the Comilla area. These schemes and other irrigation development projects in East Pakistan are being studied by the Pakistan Institute of Development Economics, and results will be reported separately. However, a number of tentative conclusions can be drawn which would be of help in the preraration of the Third Plan.

i) Ganges-Kobadak Project: The Ganges-Kobadak Project provides for pumping of water for irrigation of land in the Kushtia and Jessore districts through a network of canals. The pumphouse is located in a favourable position

54 W. J. Van Blommestein, A Multipurpose Project for the Brahmaputra Ganges Delta, (Rome: Food and Agriculture Organization, 1952).

55 FAO, A Preliminary Survey of Available Information on the Agricultural Fishery and Forestry Resources in the Lower Ganges-Brahmaputra Basin. (Rome: Food and Agriculture Organization, August 1959), p. 65.

56 United Nations, Water and Power Development in East Pakistan. (New York: United Nations, 1959).

57 International Bank for Reconstruction and Development, Economic Development Programme of Pakistan. (Washington, D.C.: International Bank for Reconstruction and Development, April 1964), p. 63. 
below the Harding Bridge, even then considerable difficulty has been experienced in keeping the intake channel clear. Working of the canal in the first season has caused considerable waterlogging because of excessive seepage from canal distribution system.

The actual area to be irrigated by canals in Phase I of Kushtia unit of the Project is only 57 per cent of the gross area. This low percentage follows from the irregular relief of land. Being a deltic region formed by deposits from the Ganges, the land surface of the Kushtia unit has quite a pronounced microrelief with considerable differences in elevation over short distances. While on the one hand, this facilitates surface irrigation and drainage, on the other it requires a very irregular pattern of canals and drains and some of the areas cannot be commanded by a canal distribution system. The area commanded by canals in Kushtia unit has been protected from floods by embankments on all sides.

The total cost of the Kushtia unit of Ganges-Kobadak Project is estimated at Rs. 200 million. The annual costs are estimated at Rs. 12 to Rs. 13 million. The Food and Agriculture Organization deputed an agricultural economist to make an economic analysis of the project. He concluded that from the point of view of overall economic feasibility the project was only marginal 58 . From a financial point of view, he estimated that only the operation and maintenance costs were likely to be recovered in the form of water charges and other revenues and there was no likelihood of sufficient revenue to pay either the interest or amortization on capital outlay. While forwarding the agricultural economist's report to the Government of Pakistan, FAO did not agree with the conclusions drawn by the expert and stated that benefit-cost ratio would vary between 1.18 and 1.49 in contrast with the expert's conclusion that Kushtia-I unit was likely to have benefit-cost ratios ranging from 0.76 to 1.0859 .

In view of the high cost involved and low benefits expected from this Project; it seems desirable to delay work on other surface canal irrigation works in East Pakistan till all aspects of canal irrigation have been fully investigated.

ii) Groundwater Development in North Bengal: Extensive experience of pumping from tubewells in the Ganges Plain in India and tests carried out in West Bengal and East Pakistan indicate that water supply in the Ganges alluvium is abundant. The recharge of the acquifer from heavy rainfall during the monsoon is likely to meet a considerable part of the

58 E. L. Greenshields, Some Economic Aspects of the Ganges-Kobadak Irrigation Development Scheme. (Rome: Food and Agriculture Organization, 1959), p. 149.

59 Ibid., p. xii. 
withdrawal during the rest of the year, and there is likely to be no problem of the watertables going deep and resulting in high pumping costs.

A project for groundwater development in the North Bengal is under execution at present. This project provides for the irrigation of 91,000 acres by 380 tubewells, and in some other areas by low-lift pumps. A powerhouse has been constructed at Thakargaon and transmission lines to wells have been laid. Tubewells were expected to commence pumping water in April 1964 when powerhouse was to be put into operation. However, till June 1964 the tubewells had not started pumping water.

The total cost of the project is Rs. 134.6 million 60 . Out of this the cost of installation of 380 tubewells only is estimated at Rs. 45.6 million which is equal to Rs. 120,000 per tubewell. The cost of electric-transmission lines is Rs. 31.7 million which is equal to Rs. 72,000 per tubewell. Total cost of each tubewell is, thus, Rs. 192,000 .

The area to be irrigated by each tubewell is 240 acres. Irrigation charges are proposed to be recovered at the rate of 68.5 per acre. Even then the working of the tubewells is proposed to be subsidized, the subsidy decreasing from Rs. 486 per acre in the first year to Rs. 25 per acre in the 7th year and Rs. 6.6 per acre thereafter. This is based on the assumption that life of tubewells will be 50 years. If a realistic life-period is adopted, the cost per acre would be much higher.

In view of the above, it would be desirable not to plan any more government tubewells in East Pakistan until the working of Dinajpur tubewells demonstrates that it is possible to recover a large part of the cost from the beneficiaries.

iii) Low-Lift Pump Irrigation: Low-lift irrigation is particularly suitable for areas subject to floods and laced with channels and ponds in which pumps can be fixed for pumping water in the dry season. In these areas construction of permanent canals and structures would be difficult. Portable units can be moved to these areas when flood waters recede and taken out of the area before next season's floods. A power pump irrigation scheme is in operation in East Pakistan for the past many years. Under this scheme about 2,000 pumps with a total capacity of 3,500 cusecs worked during $1962 / 63$ and irrigated 133,000 acres of boro paddy 61 . For $1964 / 65$, the target is 4,000 powerpumps to irrigate 390,000 acres.

60 East Pakistan, WAPDA, Groundwater Development and Pump Irrigation in the Northern Districts of East Pakistan. (Dacca: East Pakistan Water and Power Development Authority, October 1963).

61 East Pakistan, ADC, Scheme for Mechanized Cultivation and Power Pump Irrigation in East Pakistan. (Dacca: East Pakistan Agricultural Development Corporation, February 1964), p. 4. 
According to a survey by the East Pakistan WAPDA, quoted by the East Pakistan Agricultural Development Corporation, an area of about 4.4 million acres can be served by irrigation by such small pumps ${ }^{62}$. Out of this about 2.5 million acres lie in Mymensingh, Sylhet, Dacca and Comilla districts.

The major problem in the working of the scheme in the earlier years was lack of trained personnel to run the scheme and nonrecovery of hire charges. The training problem has partially been overcome by the East Pakistan Agricultural Development Corporation which achieved a target of 85 per cent in $1962 / 63$ so far as area to be irrigated was concerned. Recovery of hiro charges continues to be the main problem.

The cost of these pumps varies between Rs. 7,000 to Rs. 8,500 for a pump of 2-cusec capacity which can irrigate about 80 acres of boro paddy63. The cost of pumping water is estimated at Rs. 43 per acre, but only Rs. 27 per acre were charged in 1961/62 and Rs. 30 per acre in 1962/63. Even then the Agricultural Development Corporation were not able to make full recoveries for the hire charges on the pumping of water. For this very reason, the government decided in 1960 that small pumps should be sold to the cultivators. The Cor: poration have not been able to sell many pumps so far. They now propose that in future the charges should be collected by the Revenue Department undar the Public Demands Recovery Act.

It may be better to leave the powerpumps to the private enterprise. Instead of the government purchasing the pumps and then trying to sell them, these should be allowed to be imported free of customs duty by private trade and the farmers should be encouraged to buy their own pumps. Sale of pumps even at a subsidized rate would be far cheaper than working of the same by the government and not realizing the working charges from the beneficiaries.

The greatest possibility for extension of low-lift pump irrigation lies in Sylhet-Mymensingh depression and in parts of Dacca, Comilla and Chittagong districts where water is available in the rivers and khals during the winter season. In other districts, low supply of water in the winter months is likely to limit the extension of powerpump irrigation.

iv) Small Private Tubewells: The largest possibility for increase in irrigation in East Pakistan in the immediate future lies in small tubewells which can be installed by the farmers themselves with some assistance from the government. These tubewells can be installed even in areas which are normally inundated to some extent. 
The Pakistan Academy for Rural Development in Comilla has prepared a plan to sink 200 tubewells of 6-inch diameter at an estimated cost of Rs. 15,000 each ${ }^{64}$. Eleven of these tubewells were installed in the Comilla Kotwali Thana by January 1964. Working of these tubewells was passed on to the village cooperatives organized by the Academy and all these tubewells were put to use immediately on installation. The average discharge of the tubewells is 1.5 cusecs. The Academy considers that each tubewell will irrigate about 60 acres, but the farmers believe that they can cover as much as 100 acres on each tubewell. Even those tubewells put in at the end of January started irrigation and a late boro (saita) rice crop was sown. So far no recovery has been made but the farmers have agreed to pay the full cost of the tubewells and to work the tubewells themselves at their own cost.

\section{Comparison of Government and Private Tubewells}

A statement showing the comparative cost of a government tubewell of 4.0-cusec capacity installed in the Dinajpur area and that of a private tubewell of 1.5-cusec capacity installed in the Comilla area is given in Appendix Table B-III and is summarized below in Table IV:

\section{TABLE IV}

\section{COMPARATIVE COST OF GOVERNMENT AND PRIVATE TUBEWELLS}

\begin{tabular}{|c|c|c|c|}
\hline \multirow[b]{2}{*}{ Item of cost } & \multicolumn{2}{|c|}{ Dinajpur tubewell of } & \multirow{2}{*}{$\begin{array}{c}\text { Private } \\
\text { tubewoll } \\
\text { of } \\
1.5 \text { cusecs }\end{array}$} \\
\hline & 4.0 cusecs & $\begin{array}{l}\text { Apportioned } \\
\text { cost of } 1.5 \\
\text { cusecs }\end{array}$ & \\
\hline & \multicolumn{3}{|c|}{ 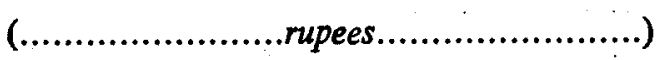 } \\
\hline Cost of tubewell & 120,000 & 45,000 & 14,500 \\
\hline $\begin{array}{l}\text { Cost of electric-transmission } \\
\text { facilities }\end{array}$ & 72,000 & 27,000 & $?$ \\
\hline Total & 192,000 & 72,000 & $?$ \\
\hline
\end{tabular}

Source: Appendix Table B-III.

Total cost of the government tubewell exclusive of electric-transmission facilities is more than 3 times that of the private tubewell when both are measured on the basis of equal discharges. It would, therefore, be preferable to encourage the installation of private tubewells and not of governmental tubewells.

64 Pakistan Academy for Rural Development. A New Co-operative System for Comilla Thana, Third Annual Report. (Comilla: Pakistan Academy for Rural Development, 1963), pp. 70-71. 
Installation of private tubewells can be rapidly expanded if 100 handdrilling rigs are imported annually. In this way, a programme for the installation of 1,000 tubewells a year in the beginning of the third-plan period rising to about 5,000 tubewells a year by the end of the third-plan period and about 10,000 tubewells a year by the end of the fourth-plan period can be achieved. Total number of tubewells can reach about 15,000 in 5 years and about 50,000 in 10 years. The total cost for the third-plan period is likely to be about Rs. 200 million. The cost during the fourth-plan period may reach some Rs. 600 million. Critical problems likely to be faced by the farmers in this programme are:

a) Provision of construction material: Supply of blind pipes, strainers, pumps, motors and engines are likely to be one of the bottlenecks in the installation of tubewells. For rapid expansion of the programme adequate arrangements should be made for these items.

b) Supply of electric power or diesel oil to run the tubewells: In order to make the best use of existing resources, these tubewells could be first installed along the existing or planned electric transmission lines. In areas where electric power is not available provision of diesel oil is likely to be a bottleneck. Arrangement should be made for supply of diesel oil in all such areas.

c) Credit availability: Credit facilities on a scale somewhat larger than that in West Pakistan would be required by the farmers in all areas where tubewells are installed.

It should be possible to cover about 200 acres per tubewell when diversified cropping is adopted. Total area annually irrigated from tubewells would, thus, be about 3 million acres by the end of the third-plan period and about 10 million acres by the end of the fourth-plan period. Including low-lift pump irrigation, the total area would be 4 million acres by the end of the third-plan period and 12 million acres by the end of the fourth-plan period.

\section{Drainage}

Removal of excess water by drainage is as important as provision of irrigation water in the time of failure of rainfall in East Pakistan. While the major flood-control and drainage programmes of WAPDA will take time, localized drainage congestion can be improved by digging small drains under the Works Programme which has been under way in East Pakistan during the last 2 years. It already may have had a marked influence on raising the rice yields in 1963/64 season 65. Digging of drains under the Works Programme should, therefore, be intensified.

65 See, R. V. Gilbert, The PL-480 Programme for the Third Plan. (Karachi: March 9, 1964. Mimeographed.) 
Extensive use of fertilizer, small tubewells installed by the farmers and small drains excavated under the Works Programme may provide an answer to East Pakistan's major agricultural problems of low productivity.

\section{Prospects}

Floods and droughts are the principal causes of low crop-production in East Pakistan. However, control of floods in East Pakistan is likely to be exceedingly difficult and costly. It will take many years of resolute efforts to plan and implement major flood-control programmes.

Our examination of the present irrigation projects in East Pakistan indicates that construction of canals will need flood-protection measures in a large part of East Pakistan. Water will have to be pumped from the rivers, only a part of the cultivated area will be commanded by surface canals and cost of irrigation will be extremely high. Major canal-irrigation projects now planned should, therefore, be held in abeyance until the economics of alternative development programmes have been investigated. Similarly, tubewells installed by the government along the lines of the Dinajpur tubewells are likely to be too costly for farmers to pay the full working cost. On the other hand, low-lift power pumps and small tubewells installed by the farmers with some assistance provided by the government are likely to prove very profitable. Possibility for expansion of low-lift pump irrigation is likely to be limited to Sylhet-Mymensingh depression and Dacca, Comilla and Chittagong districts where perennial water supply is availatle for winter irrigation. Small tubewells can be installed in almost all areas of East Pakistan. Installation of these tubewells could expand as rapidly in East Pakistan in the next few years as it has in West Pakistan in the past few years. A programme for the installation of 1,000 tubewells a year can be initiated immediately if 100 drilling rigs along with blind pipes, pumps, motors and engines are imported. This programme can be expanded fast enough to cover a major part of the province within the next 10 years. These tubewells can be installed even in areas which are normally inundated to some extent without execution of any flood-control measures.

\section{IV: CONCLUDING REMARKS}

We have shown in this paper that the problem of low agricultural productivity in large areas of Pakistan can be solved, to a large extent, by concentrating on two vital sectors, namely, fertilizer and water. This may appear out of line with current thinking on the subject which puts great stress on building up a large and efficient extension service and on providing all factors of production such as seed of improved varieties, fertilizer, plant-protection equipment and chemicals, improved implements and credit in a "package programme" as recommended by the Food and Agriculture Commission. It may also appear 
opposed to the proposals for concentrating all the production factors alongwith a large extension and other staff from all development departments on "project areas" as recommended by the Revelle Report or in "selected districts" under the "crash programme" or "model scheme".

It is important that we are not misunderstood at this point. The long-run need of an efficient extension service and of other factors of production is not denied. What is, however, contended is that a very large increase in agricultural production can be brought about with the existing extension services and without making large provision for other complementary factors. Given cheap fertilizer and adequate water supply, farmers in substantial parts of Pakistan are likely to bring about very large increases, probably more than 100 per cent, in agricultural production within a few years with only moderate provision for other factors of production.

In other words, we stress that though all factors are important, priorities still do exist. Time in Pakistan is important and we must take advantage of those factors and those areas where a quick response to key inputs may be expected. Those do not have to be limited to specific project-areas of a million acres or so but can be extended rapidly over a very large part of the country.

If adequate number of demonstration trials are laid out in each Union by training the existing extension staff, the rate of increase of fertilizer consumption will mainly depend upon the profitability of its use and, therefore, the cheapest and the best combination of fertilizers should be made available. If price of fertilizer is high, no extension service can succeed in bringing about a large increase in fertilizer use by the farmers. If the price is low, and adequate incentives for distribution are established, the initiative of farmers themselves may be relied upon to bring about substantial increases in consumption with the help of existing extension services.

Similarly, expansion of water use by the farmers will depend upon its profitability. If a tubewell costs Rs. 90,000 (as in SCARP 3) or Rs. 120,000 (as in North Bengal) exclusive of electric-transmission facilities and the annual cost of water comes to Rs. 68.5 per acre, the farmers are not likely to pay and expand the use of such water, no matter how efficient the extension service is. If, on the other hand, cheap tubewells costing Rs. 10,000 each or less are installed and the government can provide cheap electricity to the farmers to run the tubewells, there will be a rapid expansion in the installation of tubewells and in the use of water.

The present varieties of crops, particularly of rice and wheat, would need replacement with stiff-strawed varieties which can stand high doses of fertilizers 
and water. Research work in Pakistan should be geared to that end. Whenever seed of such a variety becomes available it will be rapidly taken up by the farmers. The present varieties of crops can, however, use 800,000 tons of nitrogen, phosphorus aud potash a year without any difficulty.

As incomes of the farmers increase by the use of fertilizer and water, they will begin to use larger quantities of all other inputs like pesticides and chemicals, better equipment and machinery. Larger areas would be devoted to fruits, vegetables, legumes, fodders and green-manure crops and complex rotations will be followed. A more elaborate extension service would then be needed. But for the present, let us concentrate on providing cheap fertilizer and cheap water to the farmers. 


\section{Appendix A}

\section{TABLE A-I}

\section{RELATIONSHIP BETWEEN THE PRICE OF NITROGEN, WHEAT AND PADDY IN JAPAN AND PAKISTAN}

\section{Nitrogen and wheat}

$\frac{\text { Japan }}{\text { (dollars per } 100 \text { kilogram) }}$

Price paid by farmers for nitrogen

Price received by the farmers for wheat

Ratio between price of nitrogen and wheat

Nitrogen and paddy

Price paid by farmers for nitrogen

Price received by the farmers for paddy

Ratio between price of nitrogen and paddy

Sources: a) FAO, Fertilizer: Annual Review for 1962. Table XXVIII.

b) FAO, Production Yearbook 1962. Table 126.

c) Ibid Table 133.

d) On the basis of actual sale price of ammonium sulphate of Rs. 8.00 per bag of 112 pounds fixed in West Pakistan in January 1964.

e) On the basis of actual wholesale price of wheat of Rs. 13.75 per maund of 82.3 pound prevailing in Multan market during 8 weeks between May 18 and June 6, 1963. Deduction of 20 per cent made to get the harvest price of Rs. 11.0 per maund. (Source: Markets and Prices, May, June and July 1963). $f$ ) On the basis of actual sale rate of Rs. 10.12 per maund (82.3 pounds) of urea in
East Pakistan.

g) On the basis of wholesale price of Rs. 15.81 per maund of paddy in 48 markets of East Pakistan during the first 8 weeks of 1964, published in the Weekly Price Bulletin issued by the Directorate of Agricultural Marketing, East Pakistan, Dacca. Deduction of 20 per cent made to arrive at the price received by the farmers. 


\title{
Appendix B
}

\author{
TABLE B-I
}

COMPARATIVE COST OF GOVERNMENT AND PRIVATE TUBEWELLS IN THE PUNJAB

\begin{tabular}{|c|c|c|c|c|c|}
\hline \multirow{3}{*}{ Item } & \multirow[b]{2}{*}{$\begin{array}{l}\text { SCARP.1 } \\
\text { tubewell } \\
\text { of } 3.0 \\
\text { cusecs }\end{array}$} & \multirow[b]{2}{*}{$\begin{array}{c}\text { SCARP-2 } \\
\text { tubewells } \\
\text { of } 3.55 \\
\text { cusecs }\end{array}$} & \multicolumn{2}{|c|}{ SCARP-3 Tubewell } & \multirow[b]{2}{*}{$\begin{array}{l}\text { Private } \\
\text { tubewell } \\
\text { of } 1.25 \\
\text { cusecs }\end{array}$} \\
\hline & & & 3.9 cusecs & $\begin{array}{c}\text { Appor- } \\
\text { tioned } \\
\text { cost for } \\
1.25 \text { cusecs }\end{array}$ & \\
\hline & (1) & (2) & (3) & (4) & (5) \\
\hline \multirow{2}{*}{\multicolumn{6}{|c|}{ 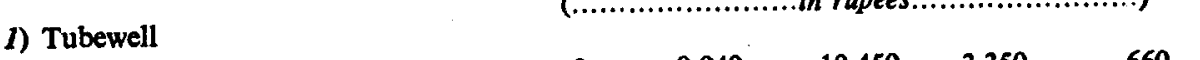 }} \\
\hline & & & & & \\
\hline $\begin{array}{l}\text { ii) Electric log } \\
\text { iii) Housing casing or pipe }\end{array}$ & $\dot{?}$ & 560 & $\begin{array}{r}560 \\
2310\end{array}$ & $\begin{array}{r}3,180 \\
740\end{array}$ & 1.080 \\
\hline $\begin{array}{l}\text { ii) Housing casing or pipe } \\
\text { iv) Grainer } \\
\text { v) Gravel shrouding }\end{array}$ & $?$ & $5,350 a$ & $7,360 \mathrm{a}$ & $2,360 \mathrm{a}$ & $\begin{array}{l}1,000 \\
590\end{array}$ \\
\hline $\begin{array}{l}\text { v) Gravel shrouding } \\
\text { vi) Developing and testing }\end{array}$ & $\stackrel{?}{?}$ & $\begin{array}{l}3,220 \\
2,630\end{array}$ & $\begin{array}{l}3,450 \\
2,630\end{array}$ & $\begin{array}{r}1,110 \\
840\end{array}$ & 二 \\
\hline $\begin{array}{l}\text { vii) Concrete base and slab } \\
\text { viii) Pump, motor and controls }\end{array}$ & $\stackrel{?}{?}$ & $\begin{array}{r}640 \\
14,470\end{array}$ & $\begin{array}{r}640 \\
14,010\end{array}$ & $\begin{array}{r}200 \\
4,490\end{array}$ & $3, \overline{680}$ \\
\hline $\begin{array}{l}\text { ix) Installation of pump and mo- } \\
\text { tors }\end{array}$ & ? & 1,550 & 1,550 & 500 & 270 \\
\hline x) Pumphouse and operators' & $?$ & 2,500 & 4,240 & 1,360 & 1,060 \\
\hline$x i) \begin{array}{l}\text { quarter } \\
\text { Wand }\end{array}$ & $?$ & 2,000 & 3,140 & 1,000 & - \\
\hline$x i i)$ Spare parts and other items & ? & $?$ & 1,560 & 500 & 460 \\
\hline Total tubewell & 40,400 & 45,200 & 51,900 & 16,630 & 7,800 \\
\hline $\begin{array}{l}\text { 2) Investigation, planning and project } \\
\text { preparation }\end{array}$ & $?$ & 260 & 4,200 & 1,350 & 一 \\
\hline $\begin{array}{l}\text { 3) Construction, operation, mainte- } \\
\text { nance equipment and facilities }\end{array}$ & 8,930 & ? & 3,760 & 1,200 & - \\
\hline $\begin{array}{l}\text { 4) Administration, engineering and } \\
\text { supervision }\end{array}$ & 2,030 & 6,380 & 6,960 & 2,230 & - \\
\hline 5) Contingencies & ? & $\mathbf{2 , 4 2 0}$ & 6,260 & 2,010 & - \\
\hline 6) Interest during construction & $?$ & $?$ & 6,640 & 2,130 & - \\
\hline Total rows (1) to (6) & 51,360 & 54,260 & 79,720 & 25,550 & 7,800 \\
\hline $\begin{array}{l}\text { 7) Drainage works for removal of } \\
\text { saline water }\end{array}$ & 一 & 19,980 & 12,250 & 3,930 & - \\
\hline Total rows (1) to (7) & 51,360 & 74,240 & 91,970 & 29,480 & 7,800 \\
\hline 8) Electric-transmission facilities & 32,100 & 41,520 & 49,810 & 15,960 & $?$ \\
\hline Grand total rows (1) to (8) & 83,460 & 115,760 & 141,780 & 45,440 & ? \\
\hline
\end{tabular}

a) Includes some blind pipe.

Sources: Col. (1) Calculated from Table 2 in Review of Project Number One: Salinity Control Programme in West Pakistan, op. cit., p. 35.

Col. (2) Calculated from Appendix $G$ in Feasibility Report on Salinity Control and Reclamation Project Number Two, op. cit., pp. G.1-G.12.

Col. (3) Calculated from Tables E-2 to E-6 from Feasibility Report on Salinity Control and Reclamation Project Number Three, op. cit., pp. E-3-E-5.

Col. (4) Calculated from Col. (3) by dividing each figure by 3.12.

Col. (5) Calculated from data collected from 22 private tubewells in the Punjab. 


\section{TABLE B-II}

\section{COST OF IRRIGATION FROM PRIVATE TUBEWELLS IN THE PUNJAB}

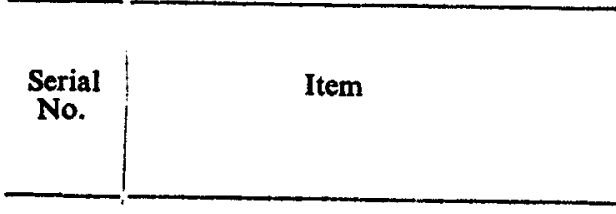

Cost for a dieseldriven engine tubewell of one-cusec capacity

(1)
Cost of an electricdriven tubewell of 1.25-cusec capacity

(2)

(....... in rupees per day

1) Interest on capital at 4 per cent

2) Depreciation at 10 per cent

3) Oil or electric consumption:

i) Diesel oil at Rs. 1.50 per gallon and mobile oil at Rs. 6.00 per gallon

ii) Electricity at 0.08 per unit

4) Pay of driver

5) Area irrigated in 8 hours (acres)

6) Cost per acre (rupees)

7) Cost of irrigation per hour (rupees)
7.19

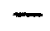

8.81

\subsection{5}

2.25

Total:

17.81

15.02

3

3.75

5.94

4.00

2.25
1.12

2.84 


\section{TABLE B-III}

COMPARATIVE COST OF GOVERNMENT AND PRIVATE TUBEWELLS

IN EAST PAKISTAN

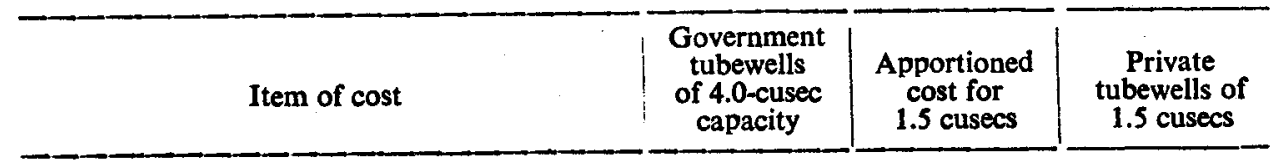

$($.

rupees.

Field cost

1) Loading and transport of plant and materials

2) Construction of tubewells

2,920

27,520

3) Developing and testing

1,860

4) Pump, motors and accessories

13,650

5) Pumphouse and pumps

6,670

6) Distribution channels

7) Operators' quarters

8) Field headquarters

9) Transport

10) Subtotal rows $1-9$

1I) Contingencies

12) Subtotal field cost Rows 10-11

13) Customs duty and sales tax

14) Engineering and investigation

15) Establishment

20,000

2,520

4,470

640

80,250

4,010

$-74,260$

7,880

8,820

2,530

16) Subtotal rows 12-15

17) Land

\begin{tabular}{|c|c|c|}
\hline 103,490 & 38,810 & 13,250 \\
\hline 3,000 & 1,120 & - \\
\hline 106,490 & 39,930 & 13,250 \\
\hline 5,320 & 2,000 & 1,290 \\
\hline 8,260 & 3,100 & ? \\
\hline 120,070 & 45,030 & 14,540 \\
\hline 72,090 & 27,030 & $?$ \\
\hline 192,160 & 72,060 & $?$ \\
\hline
\end{tabular}

Grand total rows 21 and 22

18) Subtotal row 16-17

19) Overhead

$$
\begin{array}{r}
1,100 \\
10,320 \\
700 \\
5,120 \\
2,500 \\
7,500 \\
940 \\
1,680 \\
240
\end{array}
$$

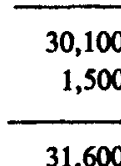

2,950

13,250

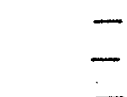

20) Interest during construction

21) Total tubewell rows $18-20$

22) Electric-transmission lines 


\section{Appendix C}

\section{Kinds of Fertilizers Suited to Pakistan}

\section{Urea}

The only raw material required for the production of urea is natural gas. Its cost of production per unit of nitrogen is the lowest of all nitrogenous fertilizer ${ }^{1}$. It contains 46 per cent nitrogen, the highest of all fertilizer, and has an advantage of substantial saving in the cost of bagging, handling and transportation per unit of nitrogen compared to other fertilizers. For these reasons, urea is gaining an important position in nitrogen-fertilizer industry in all countries, particularly where sulphur is scarce. In comparative trials in East Pakistan it has been found to be slightly superior or equal to ammonium sulphate as a source of nitrogen. Although such trials have not been conducted in West Pakistan, it is likely to be as good a source of nitrogen as any other fertilizer. It should, therefore, be the principal nitrogenous fertilizer to be produced in both provinces.

\section{Ammonium Sulphate Nitrate}

Ammonium sulphate nitrate contains 26 per cent nitrogen, of which $1 / 4$ is nitrate nitrogen and $3 / 4$ ammonia nitrogen. In experiments carried out in West Pakistan, ammonium sulphate nitrate has given considerably higher yields than ammonium sulphate. Ammonium sulphate nitrate has not yet been compared against urea. If it shows better results than urea, a plant to produce ammonium sulphate nitrate from gypsum may be located in the salt-range area. But there is no justification in producing ammonium sulphate nitrate and ammonium sulphate at Karachi and Mari with costly imported raw material as recommended by Imhausen 2 .

\section{Compound Fertilizers}

Imhausen recommend production of one million tons of compound fertilizer as a source of nitrogen and phosphoric acid for West Pakistan ${ }^{3}$. The main advantage of compound fertilizer is the saving in labour cost in the application of fertilizer to the crops. This is not a problem in Pakistan. The main drawback of compound fertilizers is that these can be produced only with imported rock phosphate, imported sulphur and ammonia produced from

1 Cost of production per ton of nitrogen is estimated at $\$ 162$ for urea, $\$ 172$ for calcium ammonium nitrate, $\$ 183$ to 187 for ammonium sulphate and $\$ 190$ for compound fertilizer. See, Report on Development of Fertilizer Industry in Pakistan, op. cit., pp. 104-109.

2 lbid., pp. 164-168.

3 Ibid. 
natural gas: The cost of production per unit of nitrogen and phosphoric acid in compound fertilizer is higher than single fertilizers, and foreign exchange will be required year after year for the import of raw materials. Another drawback of compound fertilizers is that farmers have no way of prejudging the quality of plant nutrients in relation to the specific needs of crops and soils. Thus, too little of some nutrients and too much of others is applied and the total cost of fertilizer to the farmer becomes high. In West Pakistan even the Department of Agriculture does not yet know where and in what combinations nitrogen and phosphates are necessary. Therefore, until appropriate experimentation under a variety of soil and climatic conditions throughout the province has been done, the production of compound fertilizers would seem to be premature.

\section{Rock Phosphate}

Rock phosphate can be used in place of triple superphosphate for the wet paddy crop on the acid soils of East Pakistan. Ordinarily, the effect of rock phosphate is not very spectacular in the first year, but benefits become evident in later years. Therefore, a higher dose is used in the first year to get good results. However, it has been observed in India, the United Kingdom and the Soviet Republics that the application of rock phosphate gives results equivalent to manufactured phosphate under certain conditions ${ }^{4}$. In the wet regions of the United Kingdom, spectacular results have been obtained on acid soils in the first year by the use of North-African phosphate rock on turnips. In many instances the increase in yield were almost identical with those obtained from dressings of superphosphate containing an equal amount of phosphorus. Similarly, on some acid soils in India, phosphate rock and bone meal have proved to be even better than superphosphate for wet paddy. It is, therefore, very probable that on wet paddy crop grown on the acid soils of East Pakistan, rock phosphate will prove as effective as triple superphosphate over a number of years. Since it costs only one-third as much as triple superphosphate in foreign exchange, the best policy would be to import the rock phosphate, grind it finely and supply it to the farmers. It can be sold very cheaply and is likely to boost the sale of all fertilizers.

\section{Single Superphosphate}

For West Pakistan single superphosphate is likely to be better than triple superphosphate. Its cost of production per unit of $\mathrm{P}_{2} \mathrm{O}_{5}$ is lower than triple superphosphate and it contains more than 50 per cent calcium sulphate, which is likely to be of great value for crops on the irrigated areas of West p. 77 .

4 FAO, Efficient Use of Fertilizers. (Rome: Food and Agriculture Organization, 1960), 
Pakistan. Insufficient calcium is considered to be one of the major causes of low yields in the irrigated areas of West Pakistan5. Application of calcium sulphate or gypsum should, therefore, increase crop yields in West Pakistan. It was recommended in 1953 by FAO that gypsum should be supplied to farmers for use on the most productive and well-drained soils all over West Pakistan. Unfortunately, no action has been taken on this by the West Pakistan Government. Application of single superphosphate would provide one way of adding the much needed calcium to the soil in addition to the phosphoric acid. Single superphosphate is, therefore, likely to be much more profitable than the triple superphosphate for West Pakistan.

It may be pointed out that triple superphosphate is produced mainly in the United States where the manufacturing plants are able to use low-grade rock phosphates which have lower commercial value for the manufacture of single superphosphate. The main advantage of triple superphosphate is in saving in transport cost of the finished material. The triple superphosphate plants are usually located near the rock phosphate mines and the concentrated superphosphate can be transported long distances because of lower transport cost per unit of the phosphoric acid. The single superphosphate plants are on the other hand located in the areas where the fertilizer is to be used. The phosphate content of phosphate rock is about 33 to 37 per cent which is nearly twice that of the single superphosphate and it is, therefore, cheaper to transport the rock than the single superphosphate. The single superphosphate plants should, therefore, be located throughout the farming area of West Pakistan.

It may be mentioned that more than one-half of the phosphoric acid in the world is produced in the form of single superphosphate. The lower manufacturing cost per unit of phosphorus, the simplicity of the process, and the generally high nutrient value of the procuct are the principal factors that have enabled single superphosphate to maintain its superior position in the world's phosplatefertilizer industry. of Salinity in West Pakistan. (Rome: Food and Agriculture Organization, September 1953). 